\title{
Determination of Intergeneration Differences of Nurses and Student Nurses About Lifelong Learning in The Changing World: Eastern Black Sea Sample
}

\author{
Ayten Yilmaz Yavuz ${ }^{1}$ \\ ${ }^{1}$ Department of Public Health Nursing Recep Tayyip Erdogan University School of Health, Rize, Turkey \\ Received: 11 October 2019, Accepted: 12 April 2020, Published online: 30 April 2020 \\ (C) Ordu University Institute of Health Sciences, Turkey, 2020
}

\begin{abstract}
Objective: Advances in medicine and technology have caused professional knowledge to develop and change. The aim of the present study is to find out the intergeneration differences of nurses and student nurses about lifelong learning in the changing world.

Methods: This descriptive study was conducted on 532 student nurses and nurses in a city of Eastern Black Sea region. The data were collected through a questionnaire form prepared to find out the views of nurses about lifelong learning. Descriptive statistics and Chi-square test were used in the assessment of data.

Results: One third of the participants who were student nurses were in their third of study and nurses were found to be working in the profession with a mean of five years. It was found that the participants thought it should be obligatory for nurses to participate in continuing education activities so that they can work in health institutions. It was found that $68.5 \%$ of the nurses preferred applicability feature and $82.6 \%$ preferred visual and audio educational materials in lifelong learning programs. It was found that nurses participated in educational programs more and $84.4 \%$ of the nurses were found to have received basic electrocardiography education and $60.8 \%$ of the nurses stated that they would like to receive education on nutrition nursing. It was found that nurses wanted to participate in education programs for professional development, while student nurses wanted to participate for career development.

Conclusions: It can be seen that nurses working participated in education programs more and wanted to participate in educational activities if they were given the opportunity. The awareness for lifelong learning and reaching related programs should be raised starting from years at the university and these studies should be included in the curriculum so that nurses can hear about professional development and changes.
\end{abstract}

Key words: Thyroid, Benign, Malignant, Multicentricity

Suggested Citation: Yilmaz Yavuz A. Determination of Intergeneration Differences of Nurses and Student Nurses About Lifelong Learning in the Changing World: Eastern Black Sea Sample. Middle Black Sea Journal of Health Science, 2020; 6(1): 28-36

Address for correspondence/reprints:

Ayten Y1lmaz Yavuz

Telephone number: +90 (464) 21410 59/3913
E-mail: ayten.yilmaz@erdogan.edu.tr

DOI: $\quad 10.19127 / \mathrm{mbsjohs} .649153$

ORCID-ID 0000-0002-5861-4254 


\section{Introduction}

In nursing profession, lifelong learning is very important in terms of members of the profession following up-to-date information and practices in the field of health (Hirst et. al., 2017). Nurses' being able to have the information, skills and competence that they need for safe nursing practices, maintaining health care services with high quality and improving these services show the necessity for nurses to learn continually during their lives (Hirst et. al., 2017; Brunt, 2019). Especially American Nurses Association (ANA), American Association of Critical-Care Nurses (AACN) and a great number of accredited institutions emphasize the lifelong learning responsibilities of nurses (Dee and Reynold, 2013; Dawis et.al., 2014). Competence of students of nursing department, who are prospective nurses of today and nurses of tomorrow, in lifelong learning will be effective in creating healthy social change (Dikmen et al., 2016). At the same time, within the context of tenth development plan prepared to increase the society's level of welfare, the need "to give individuals the skills and competence required by working life considering the perspective of lifelong learning and to improve man power in health" was emphasized $\left(10^{\text {th }}\right.$ state development plan).

Lifelong learning in nursing is defined as a dynamic process that covers both personal and professional life and it includes both formal and informal process. Lifelong learning includes gaining a new perspective and at the same time researching and appreciating new worlds or ideas to question life, knowledge, skills and interactions. The most basic characteristics of lifelong learners can be listed as reflection, investigation, enjoying learning, understanding the dynamic nature of information and participating in learning by using active learning opportunities. Keeping the mind active is necessary for both lifelong learning and for turning knowledge into the capacity to provide high quality nursing care (Dawis et al., 2014).

Working in a profession is a significant trigger for professional development irrespective of age. Fulfilling new tasks outside the unit individuals work in or fulfilling new duties encourage learning. In addition, experiences in personal life can contribute in terms of nurses' professional development. In addition to these similarities, data have shown differences in personal life and professional life which has been found to be associated with differences in professional development strategy. It has been reported that especially younger nurses aim for "balance between profession and personal life", while middle aged nurses aim for "consistency in profession" and older nurses aim for "career and experience" (Pool et. al., 2015). When lifelong learning was examined in different professions, it was found that a study was conducted to assess the knowledge and awareness of managers of public library and librarians about lifelong learning and the results showed that $41.4 \%$ of the participants were not informed in university about lifelong learning and at the same time $86.0 \%$ of the participants did not receive in-service training about lifelong learning (Ersoy and Yilmaz, 2009). In line with these results, it can be seen that necessary interventions are not made for lifelong learning in university education and professional life.

When the average ages of working nurses were examined, about $40 \%$ were in $\mathrm{X}$ generation (born between 1965 and 1980) and 60\% were born in Y generation (millennium generation, born between 1981 and 2000), and $X$ and $Y$ generation nurses were found to work actively in the profession (Sherman, 2006; Yilmaz Esencan and Ozdil, 2017). X generation individuals are open minded individuals who have feelings of cooperation and liberty and who like things they can feel comfortable with in their lives (Takase et al., 2007). Y generation individuals care about the balance between professional life and personal life and they expect a fun and innovative professional life (Yilmaz Esencan and Ozdil, 2017). Giving opportunities to increase their professional content and quality of life to nurses who are actively working will increase level of contentment both for nurses and patients. When it is considered that a great majority of nursing students also consist of $\mathrm{Y}$ generation and $\mathrm{Z}$ generation which includes deep sensuality (crystal children born after 2000), finding out their views about lifelong learning is very important in terms of showing the differences in the changing world.

Questioning the current states of nurses and student nurses about lifelong learning with the present study will contribute to lifelong adjustments that can be made. The aim of the present study was to find out the intergeneration differences of nurses and student nurses in terms of lifelong learning in the changing world through Eastern Black Sea sample.

\section{Methods}

\section{Study Design and Setting}

This descriptive study was conducted to find out the views of nurses and student nurses about lifelong learning. The universe of the study consists of 300 nursing students studying at the Health School of a 
university in Eastern Black Sea region during the 2017-2018 Academic Year and 300 nurses actively working in Research and Training Hospital. Sample was not chosen, and the sample was formed with a total of 532 participants, 285 nursing students and 247 nurses, who agreed to participate in the study. The aim was to find out the intergeneration differences between the groups. The inclusion criteria were being nursing department student in the Health School of the university, a nurse working in the Research and Training Hospital and agreeing to participate in the study.

\section{Data collection}

The data were collected by the researcher with face-to-face interview method by using questionnaire form in 10-15 minutes.

\section{Instruments}

In data collection, "Views on Lifelong Learning Form" prepared in line with the literature was used to find out participants' socio-demographic characteristics (age, income, marital status, monthly income, level of education, years in the profession, years in the current hospital, unit nurses worked in and job in the institution) and their views on lifelong learning. Views on Lifelong Learning Form includes questions about the necessity of lifelong learning education, questioning participants' views on lifelong learning, their wishes to participate in such education, the necessity of having such education to work in health institutions, the characteristics lifelong learning should have, materials and tools preferred in lifelong learning, education programs they received within the context of lifelong learning or education programs they would like to receive if they were given the opportunity and the reasons.

\section{Data analysis}

The data were assessed with IBM SPSS 23.0 (Chicago, USA). Descriptive statistics (frequency, percentage, average) and Chi-square test were used in the assessment of data. $\mathrm{p}<0.05$ was considered as statistically significant.

\section{Ethical consideration of study}

Before starting the study, written permission was taken from the institution the study was conducted in and approval from Recep Tayyip Erdogan University Non-interventional Clinical Researches Ethics Board (decision number: 2018/30, 16.02.2018). In addition, the participants were informed about the study and they were told that their personal information would be protected and those who volunteered were included in the study.

\section{Limitation of the study}

The study was limited to nurses working in a training and research hospital in the northeast of Turkey and nursing students studying in Health School.

\section{Results}

When the distribution of the descriptive characteristics of the participants were examined, it was found that mean age of the student nurses was $20.89 \pm 1.72$ (min: 17; max:29) years, $98.2 \%$ were single, $51.2 \%$ were found to have equal income and expenditure, $28.8 \%$ were found to be in their third year of study. Mean age of the nurse group was found as $26.00 \pm 6.78$ ( $\min : 20$; $\max : 54$ ) years, $84.2 \%$ were female, $57.1 \%$ were single, $44.9 \%$ were found to have equal income and expenditure, $59.1 \%$ were found to have undergraduate or higher level of education, $60.7 \%$ were found to be working in surgical clinics, with a mean working years of $5.00 \pm 6.73$ (min: 1 ; max: 35), while $89.1 \%$ working as clinic nurses with a mean of $3.00 \pm 5.38$ (min: 1; max: 35) (Table 1-2).

Table 1. Descriptive characteristics of student nurses $(\mathrm{n}=285)$

\begin{tabular}{lcc}
\hline Characteristics & n & $\%$ \\
\hline Age & Mean \pm SD (min; max) \\
Gender & $20.89 \pm 1.72$ (min: 17; max:29) \\
Female & 215 & 75.4 \\
Male & 70 & 24.6 \\
Marital status & & \\
Married & 5 & 1.8 \\
Single & 280 & 98.2 \\
Monthly income level & & \\
Income higher than expenditure & 30 & 10.5 \\
Income equal to expenditure & 146 & 51.2 \\
Income lower than expenditure & 109 & 38.2 \\
Year of study & & \\
1st year & 66 & 23.2 \\
2nd year & 77 & 27.0 \\
3rd year & 82 & 28.8 \\
4th year & 60 & 21.1 \\
\hline
\end{tabular}

In the distribution of the participants' views about lifelong learning, it was found that participants' views about the necessity of professional lifelong learning, their wishes to participate in lifelong learning activities for professional development, considering learning new information or skill as an indispensable part of life were not found to be statistically significant $(p>0.05)$. The state of thinking that it should be obligatory to participate in lifelong learning activities for the permission to work in health 
institutions was statistically significant in terms of profession groups and that nursing group thought that participating in lifelong learning activities should be obligatory more than the student group $(p<0.05)$. When the participants were asked about what features lifelong learning program should have, it was found that $68.4 \%$ of the participants thought they should be applicable by students, while $82.6 \%$ thought that visual and auditory educational materials were preferred by students (Table 3).

Table 2. Descriptive characteristics of nurses $(n=247)$

\begin{tabular}{|c|c|c|}
\hline Characteristics & $\mathbf{n}$ & $\%$ \\
\hline & \multicolumn{2}{|c|}{ Median (min; max) } \\
\hline Age & \multicolumn{2}{|c|}{26.00 (min: 20; $\max : 54)$} \\
\hline Years in the profession & \multicolumn{2}{|c|}{5.00 (min: 1; max:35) } \\
\hline Years in the hospital & \multirow{2}{*}{\multicolumn{2}{|c|}{3.00 (min: 1 ; $\max : 35)$}} \\
\hline Gender & & \\
\hline Female & 208 & 84.2 \\
\hline Male & 39 & 15.8 \\
\hline \multicolumn{3}{|l|}{ Marital status } \\
\hline Married & 106 & 42.9 \\
\hline Single & 141 & 57.1 \\
\hline \multicolumn{3}{|l|}{ Monthly income level } \\
\hline Income higher than expenditure & 31 & 12.6 \\
\hline Income equal to expenditure & 111 & 44.9 \\
\hline Income lower than expenditure & 105 & 42.5 \\
\hline \multicolumn{3}{|l|}{ Level of education } \\
\hline High school & 39 & 15.8 \\
\hline Two-year degree & 56 & 22.7 \\
\hline Undergraduate and higher & 146 & 59.1 \\
\hline \multicolumn{3}{|l|}{ Unit } \\
\hline Internal medicine clinics & 61 & 24.7 \\
\hline Surgical clinics & 150 & 60.7 \\
\hline Other units & 36 & 14.6 \\
\hline \multicolumn{3}{|l|}{ Job in the unit } \\
\hline Clinic nurse & 220 & 89.1 \\
\hline Clinic head nurse & 24 & 9.7 \\
\hline Nurse manager & 3 & 1.2 \\
\hline
\end{tabular}

When the top 5 education programs received by the participants were compared between the groups, it was found that the rate of participation in education programs was higher in the nurse group and the difference was found to be statistically significant $(p<0.05)$. The education which was most received by the nurses was basic electrocardiography with a rate of $84.4 \%$. When the top 5 education programs the participants would like to participate in were compared between the groups, it was found that the nurse group was more willing to participate in education programs and the rate was found to be statistically significant $(p<0.05)$. It was found that $60.8 \%$ of the participants would like to receive nutrition nursing education if they were given the opportunity (Table 4).

When the distribution of the participants' views about their reasons and wishes to participate in education programs were analyzed, it was found that the nurse group participated for professional development and there were significant differences in terms of groups. $(p<0.05)$. It was found that nurses and student nurses would like to participate in education programs if given the opportunity and the reasons why they wanted to participate were found to show statistically significant difference $(\mathrm{p}<0.05)$ (Table 5). 


\section{Differences of Nurses About Lifelong Learning}

$\underline{\text { Table 3. Distribution of participants' views on lifelong learning }}$

\begin{tabular}{lccccc}
\hline \multicolumn{7}{c}{ Student group } & \multicolumn{2}{c}{ Nurse group } & Test and $\mathrm{p}$ value \\
\hline \multicolumn{7}{c}{$\mathrm{n}$} & $\%$ & $\mathrm{n}$ & $\%$ & \\
\hline Thinking that lifelong learning is necessary in the profession & \multicolumn{1}{l}{} \\
\hline Those who agree & 258 & 90.5 & 234 & 94.7 & $\mathrm{X}^{2}=3.374, \mathrm{p}=0.66$ \\
\hline Those who disagree & 27 & 9.5 & 13 & 5.3 & \\
\hline Wishing to participate in lifelong learning activities for professional development & \\
\hline Yes & 250 & 87.7 & 225 & 91.1 & $\mathrm{X}^{2}=1.574, \mathrm{p}=0.210$ \\
\hline No & 35 & 12.3 & 22 & 8.9 \\
\hline Thinking that learning new information and skill is an indispensable part of life \\
\hline Yes & 257 & 90.2 & 230 & 93.1 & $\mathrm{X}^{2}=1.479, \mathrm{p}=0.224$ \\
\hline No & 28 & 9.8 & 17 & 6.9 & \\
\hline
\end{tabular}

Thinking that it should be obligatory to participate in lifelong learning activities for permission to work in health institutions

\begin{tabular}{|c|c|c|c|c|c|}
\hline Those who agree & 182 & 63.9 & 180 & 72.9 & $X^{2}=17.264 p=\mathbf{0 . 0 0 0}$ \\
\hline Those who disagree & 90 & 31.6 & 43 & 17.4 & \\
\hline No opinion & 13 & 4.6 & 24 & 9.7 & \\
\hline \multicolumn{6}{|c|}{ Features that a lifelong learning program should have * } \\
\hline Motivation & 149 & 53.4 & 155 & 63.3 & \\
\hline Selectivity & 55 & 19.7 & 68 & 27.8 & \\
\hline Applicability & 191 & 68.5 & 153 & 62.4 & \\
\hline Other (innovative) & 2 & 0.7 & 1 & 0.4 & \\
\hline \multicolumn{6}{|c|}{ Instruments preferred in lifelong learning education* } \\
\hline Programmed teaching materials & 185 & 67.0 & 149 & 61.8 & \\
\hline $\begin{array}{l}\text { Visual and auditory teaching } \\
\text { materials }\end{array}$ & 228 & 82.6 & 192 & 79.7 & \\
\hline Advisor teachers & 188 & 68.1 & 158 & 65.6 & \\
\hline
\end{tabular}

*Percentages were calculated from the multiple answers given

Table 4. Comparison of the top five education programs the participants received or would like to receive if provided

\begin{tabular}{llcccc} 
& \multicolumn{2}{c}{ Nurse } & \multicolumn{2}{c}{ Student nurse } & Test and p value \\
\cline { 2 - 5 } Teaching program & n & $\% *$ & n & $\% *$
\end{tabular}

\section{Top 5 education programs received}

\begin{tabular}{llllll}
\hline 1. Basic electrocardiography & 38 & 84.4 & 7 & 15.6 & $\mathrm{X}^{2}=28.923, \mathrm{p}=\mathbf{0 . 0 0 0}$ \\
\hline 2.Family consulting & 16 & 84.2 & 3 & 15.8 & $\mathrm{X}^{2}=11.330, \mathrm{p}=\mathbf{0 . 0 0 3}$ \\
\hline 3.Research in nursing & 15 & 83.3 & 3 & 16.7 & $\mathrm{X}^{2}=10.165, \mathrm{p}=\mathbf{0 . 0 0 6}$ \\
\hline $\begin{array}{l}\text { 4.Basic life support (BLS) } \\
\text { 5.Wound care }\end{array}$ & 61 & 81.3 & 14 & 18.7 & $\mathrm{X}^{2}=42.917, \mathrm{p}=\mathbf{0 . 0 0 0}$ \\
\hline Education programs participants would like to receive if provided & 28 & 77.8 & 8 & 22.2 & $\mathrm{X}^{2}=15.355, \mathrm{p}=\mathbf{0 . 0 0 0}$ \\
\hline $\begin{array}{l}\text { 1.Nutrition nursing } \\
\text { 2.Basic electrocardiography }\end{array}$ & 65 & 60.8 & 38 & 39.2 & $\mathrm{X}^{2}=23.510, \mathbf{p}=\mathbf{0 . 0 0 0}$ \\
\hline $\begin{array}{l}\text { 3.Health law and ethical principles in } \\
\text { health }\end{array}$ & 62 & 55.4 & 51 & 44.0 & $\mathrm{X}^{2}=18.781, \mathbf{p}=\mathbf{0 . 0 0 0}$ \\
\hline $\begin{array}{l}\text { 4.Trainer education } \\
\text { 5.Management in nursing }\end{array}$ & 55 & 55.0 & 45 & 44.6 & $\mathrm{X}^{2}=13.241, \mathbf{p}=\mathbf{0 . 0 0 1}$ \\
\hline
\end{tabular}

*Percentage of rows was taken 
Table 5. Distribution of participants' views on why they participate or want to participate in education programs

\begin{tabular}{|c|c|c|c|c|c|}
\hline & \multicolumn{2}{|c|}{ Nurse } & \multicolumn{2}{|c|}{ Student } & \multirow[t]{2}{*}{ Test and $p$ value } \\
\hline & $\mathbf{n}$ & $\%$ & $\mathbf{n}$ & $\%$ & \\
\hline \multicolumn{6}{|c|}{ Reasons why they participated in education programs previously } \\
\hline $\begin{array}{l}\text { Professional } \\
\text { development }\end{array}$ & 13 & 76.5 & 4 & 23.5 & $X^{2}=6.744$ \\
\hline Career development & 4 & 36.4 & 7 & 63.6 & $\mathrm{p}=0.034$ \\
\hline No reason given & 230 & 45.6 & 274 & 54.4 & \\
\hline \multicolumn{6}{|c|}{ Reasons why they would like to participate in education programs if provided } \\
\hline $\begin{array}{l}\text { Professional } \\
\text { development }\end{array}$ & 26 & 49.1 & 27 & 50.9 & $X^{2}=40.719$ \\
\hline Career development & 13 & 15.1 & 73 & 84.9 & $\mathrm{p}=0.000$ \\
\hline No reason given & 208 & 52.9 & 185 & 47.1 & \\
\hline
\end{tabular}

* Percentage of rows was taken

\section{Discussion}

In this section, the results of the study were analyzed regarding the intergeneration differences between participants' views on lifelong learning.

In the present study, it was found that participants thought nurses should be obliged to participate in lifelong learning activities for permission to work in health institutions (Table 3). Studies conducted show that managers of institutions define the concept of lifelong learning (LLL) with metaphors such as "obligation, human product, life, continuity, health and guiding" and emphasized the significance and necessity of LLL. Health professionals have also stated that LLL approach should be made more widespread (Dogan and Kavtelek, 2015). It is stated in the studies that nurses think that continuous education is necessary in order to provide quality health care and to save lives (Caporiccio et al., 2019).

According to another study conducted, generation $\mathrm{Y}$ workers change their jobs due to their wishes of education and development. Caring about education and development opportunities is very important in terms of expectations from professional life (Metin and K1zildag, 2017). In the present study, the fact that especially working generation $\mathrm{Y}$ nurses were aware of this situation is an indicator that they are aware of their needs for lifelong learning in terms of professional development.

In terms of the features a life-learning program should have, it was found that the features of being applicable by students and visual and auditory educational materials were preferred (Table 3). According to literature, it has been stated that there are no significant differences between generations $Y$ and $\mathrm{Z}$ in terms of "perceptive-intuitional", "visualauditory" and "sequential-integrated" learning styles. It is stated that when compared with generation Y, generation $\mathrm{Z}$ prefers perceptive-intuitional learning, while generation Y prefers "visual-auditory" and "sequential-integrated" learning (Kavalci and Unal,
2016). In addition, generation $Y$ shows that they are more inclined to lifelong learning with their beliefs that they can succeed when they want, their ambition to promote quickly, their entrepreneurial spirit, their sophistication and their command on technology (Erden, 2017). When considered that "seen-heardtold-done" information provide $90 \%$ permanence (Hacialioglu, 2013), it is thought that this might be the reason why the feature of being applicable by students was the feature most wanted by the participants.

It is recommended by prospective nurses to be open to innovations, to learn how "they can access information and how they can use information" in undergraduate education and to develop these during their profession as a necessity of following technological developments in health (Nayda and Rankin, 2008). It is seen that nurses use computers at work or out of work to access continuous education and resources (Caporicio et al., 2019). With the use of materials, the number of senses can be increased in the learning process and more permanent learning can be supported. This situation shows that permanence in education process can be provided through being applicable. Studies show that self-learning increases creativity (Nayda and Rankin, 2008). In studies conducted to find out educational needs, it is emphasized that professionals' active participation should be provided and professional studies should be shared (Serbet and Ulupinar, 2010). It is advocated that by teaching students self-learning in their undergraduate education, their skills such as "criticizing, thinking and creating" can be developed and thus their curiosity to learn can be made permanent (Guclu et al., 2013). Studies have shown that using lifelong learning strategies in student nurses such as "independence in intellectual practice, cooperative learning, inquisitive thinking, permanent learning, needs based learning, learning management, suitable learning environment and development" is 
important in terms of increasing the quality of education, developing nurses' competence and increasing quality of patient care (Qalehsari et al., 2017). In addition, the emphasis was placed on the need for a more consistent and standardized nursing education in lifelong learning (Caporiccio et al., 2019). According to the literature, it is emphasized that nursing students' self-directed learning skills should be increased (Kaulback, 2020).

In the present study, it was found that there were too many educations working nurses received and the education received most by the nurses was basic electrocardiography and if they were given the opportunity, they would like to participate in more education programs and they wanted to receive especially nutrition nursing education program (Table 4). Studies have shown that in units except for intensive care and emergency units, level of knowledge is not sufficient in terms of taking and reading ECG and does not differ in terms of level of education or years of working (Dogan and Mehmet, 2012). It can be seen that a great majority of nurses think that they need in-service training and ECG is one of the top five educations they would like to receive with a rate of $10,8 \%$ (Bugdayli and Akyurek, 2017). In nursing practices, considering the active role of nurses in patient follow ups and the significance of electrocardiography education while making these follow-ups and the effect of these on patients' quality of life, it can be seen that receiving electrocardiography education is important in terms of emergency situations. The results of the study show that there are no differences between generations in terms of this and it is equally important for groups. It is a known fact that nutrition is important to maintain the continuity of life cycle from birth to death and some chronic diseases can be prevented with healthy eating habits. When nurses teach individuals eating habits that they can turn into lifestyle, the continuity of healthy life style behaviors can be increased. Considering the active role of nurses in conducting health educations, nurses can increase individuals' awareness in using health recommendations specific for the individual and thus contribute to developing the health states of individuals (Yilmaz Yavuz, 2018). The reason why nurses stated that they would like to have nutrition nursing education can be assessed as their being aware of the fact that nutrition is the basic need in increasing health care quality and as a step of providing a high quality health service.

When the participants' views on the reasons for receiving education programs were analyzed, it was found that nurse group received education for professional development and nursing students wanted to receive education for career development if given the opportunity (Table 5). In a study which was conducted on intensive care nurses who give complicated and technology assisted patient care, it was found that almost all of the nurses expected education given to contribute to professional developments, to contribute to personal development and to increase the quality of health services, and in addition education programs given were expected to increase skills of team work (Celen et al., 2007). When it is considered that generation $\mathrm{Y}$ was higher in number in the study, the fact that career expectations, which is a general characteristic of the generation, is also desired by the students shows that "expertise in a profession" is cared by students who have not started their professions yet and that they are aware of the fact that they should specialize in their field in terms of professionalism. Managers and nurse managers should be aware of career planning, management processes and career development approaches of their employees and thus guide their expectations. In addition, employees should be able to make career plans which are not confined to an organization or profession (Tatar Baykal and Yalcin, 2014).

\section{Conclusion}

In the present study which was conducted to find out the intergeneration differences between nurses' views on lifelong learning, it was emphasized that continuous education should be made obligatory to be able to work in health sector. It was concluded that especially working nurses participated in more education programs and that they would like to participate in more education activities if given the opportunity. The necessity of professional development is obvious for hearing about professional development and changes. Within this context, awareness should be built about lifelong learning and reaching related programs starting from university years and these should be included in the curriculum.

\section{Acknowledgement}

The authors are thankful to Nurse Burak Budak, Nurse Gülsüm Yıldız and hospital workers who helped in the collection of data. 
Ethics Committee Approval: Ethics committee approval was received for this study from Recep Tayyip Erdogan University Non-interventional Clinical Researches Ethics Board (decision number: 2018/30, 16.02.2018).

Peer-review: Externally peer-reviewed.

Author Contributions: Concept-AYY, DesignAYY; Supervision- AYY.; Funding-None MaterialsAYY.; Data Collection/Data Process- AYY.; Analyze or Comment- AYY.; Literature ScanningAYY; Writer of Paper- AYY.; Critical ReviewAYY.

Conflict of Interest: No conflict of interest was declared by the author.

Financial Disclosure: The author declared that this study hasn't received no financial support.

\section{References}

Brunt BA. (2019), The Importance of Lifelong Learning in Managing Risks, ANA, The Nursing Risk Management Series, http://ana.nursingworld.org/mods/archive/mod31 1/cerm203.htm.

Bugdayli G, Akyurek CE. The views of nurses about on-the-job training activites: a sample of a university hospital. Hemşirelikte Araştırma Geliştirme Dergisi (in Turkish), 2017;19(1):1425.

Caporiccio J, Louis KR, Lewis-O'Connor A, Son KQ, Raymond N, Garcia-Rodriguez IA, Dollar E, Gonzalez L. Continuing education for haitian nurses: evidence from qualitative and quantitative inquiry. Annals of Global Health, 2019;85(1):93,1-7.

Celen O, Karaalp T, Kaya S, Demir C, Teke A, Akdeniz A. The considerations about and expectations from in-service training programs of the nurses working at the intensive care units of the education hospital of Gulhane Military Medical Faculty. 2007;49(1), 25-31.

Dawis L, Taylor H, Reyes $\mathrm{H}$ Lifelong learning in nursing: a delphi study. Nurse Education Today, 2014;34:441-445.

Dee RC, Reynolds P Lifelong learning for nurses building a strong future. Medical Reference Services Quarterly, 2013;32:4, 451-458.

Dikmen Y, Denat Y, Filiz NY, Basaran H. Lifelong learning trends in nursing students. Jounals of Human Ryhytm (in Turkish), 2016;(2)1;39-45
Dogan HD, Mehmet M (2012). Determination of the Abilities of Nurses in Diagnosing the ECG Findings About Emergency Heart Diseases and Deciding the Appropriate Treatment Approaches. 2012;3(3):60-69.

Dogan S, Kavtelek C. Perceptions of lifelong learning institution administrators about lifelong learning. Abant İzzet Baysal Üniversitesi Eğitim Fakültesi Dergisi (in Turkish), 2015;15(1): 82-104.

Erden, N.S. "New Teaching methods for new generations: learning styles of generation $\mathrm{z}$ and suggestions for higher education. International Journal of Academic Value Studies 2017; 3,$12 ; 252-253$

Ersoy A, Yilmaz B Lifelong Learning and Public Libraries in Turkey. Turkish Librarianship (in Turkish), 2009;23(4): 803-834.

Guclu S, Bostan N, Tabak RS Determination of Lifelong Learning Behaviors of Dumlupınar University Nursing Department Senior Students. Kastamonu (in Turkish), 2013;21(2):459-468.

Hacialioglu N. Teaching, learning and education in nursing. Nobel Medical Bookstores (in Turkish). 2nd Press, 1stanbul. 2013

Hirst S, Lenavenec CL, Stares R Lifelong Learning, certification, and registered nursing practice: their interrelationship. papers on postsecondary learning and teaching: proceedings of the university of calgary conference on learning and teaching, 2017;2: 10-15.

Kavalci K, Unal S. A Research on Comparing Consumer Decision- Making Styles and Learning Styles in Terms of the Generation $\mathrm{Y}$ and $\mathrm{Z}$. Atatürk Üniversitesi Sosyal Bilimler Enstitüsü Dergisi (in Turkish), 2016;20(3): 1033-1050.

Kaulback MK Correlating Self-directed Learning Abilities to Lifelong Learning Orientation in Baccalaureate Nursing Students. Nurse Educ. 2020 Jan 14.

Metin S, Kizildag D. Differentiation of X and Y Generations Career Expectations: A Research in The Automotive Sector. Mustafa Kemal University Journal of Social Sciences Institute (in Turkish), 2017;14 (40): 340-363.

Nayda R, Rankin E. Information literacy skill development and lifelong learning: exploring nursing students' and academics' understandings. Australian Journal of Advanced Nursing, 2008;26 (2): 27-33. 
Pool IA, Poell RF, Berings MG, ten Cate O. Strategies for continuing professional development among younger, middle-aged, and older nurses: A biographical approach. International Journal of Nursing Studies, 2015;52 (5): 939-50.

Qalehsari MO, Khaghanizadeh M, Ebadi A. learning strategies in nursing: A systematic review. Electronic Physician, 2017;9 (10): 5541-5550,

Serbest $S$, Ulupinar $S$. The nurses whose working in a private hospitals group comments about in service education applications İ.U.F.N. Hem. Derg (in Turkish), 2010;18 (2): 98-105.

Sherman RO (2006). Leading a multigenerational nursing workforce: Issues, challenges, and strategies. OJIN: The Online Journal of Issues in Nursing, 11:2.

Takase M, Oba K, Yamashita N (2007). Generational differences in factors influencing job turnover among Japanese nurses: An exploratory comparative design. International Journal of Nursing Studies, 46:957-967.

Tatar Baykal U, Yalcin B. "Career Development", Nursing Services Management, Ulku Tatar Baykal, Emine Ercan Turkmen, Ed., Academy Press and Publishing (in Turkish), Istanbul, p: 478-508, 2014 ISBN: 978-605-64411-2-7.

The Tent Development Plan (2014-2018). Tenth development plan (in Turkish) https://pbk.tbmm.gov.tr/dokumanlar/10kalkinma_plani.pdf

Yilmaz Esencan T, Ozdil H. (2017). Evaluation of Professional commitment of $\mathrm{X}$ and $\mathrm{Y}$ generation nurses. Ege Üniversitesi Hemşirelik Fakültesi Dergisi (in Turkish) 33(3): 91-104

Yilmaz Yavuz A. "Nutrition and Health Promotion", Lifelong Health Promotion, Behice Erci, Dilek Kılıç, Derya Adıbelli, Ed., Anadolu Nobel Publishing (in Turkish), Elazı $\breve{g}$, p:332, 2018 ISBN: 978-605-83928-6-1. 